\title{
Generation of Electricity Using Microbial Fuel Cell (MFC) from Sludge
}

\author{
Eti Barua ${ }^{1,2}$, Md. Saddam Hossain ${ }^{1}$, Modhusudon Shaha ${ }^{1}$, Ekramul Islam ${ }^{1}$, Fatema Tuj Zohora ${ }^{1}$, Anica \\ Tasnim Protity ${ }^{1}$, Sanjoy Kumar Mukharjee ${ }^{2}$, Palash Kumar Sarker ${ }^{1}$, Md. Salimullah ${ }^{3}$ and Abu Hashem ${ }^{1 *}$ \\ ${ }^{I}$ Microbial Biotechnology Division, National Institute of Biotechnology, Savar, Dhaka-1349, Bangladesh, ${ }^{2}$ Department of Microbiology, Noakhali Science and \\ Technology University, Noakhali-3814, Bangladesh, ${ }^{3}$ Molecular Biotechnology Division, National Institute of Biotechnology, Savar, Dhaka-1349, Bangladesh
}

\begin{abstract}
Microbial fuel cell (MFC), recently, is considered as a promising alternative to traditional power sources as it can use microorganisms to transform chemical energy of organic compounds into electricity. In future, microbial production of electricity may become an important form of bioenergy because electricity extraction is possible through MFC using wide range soluble or nonsoluble complex organic wastes as a renewable biomass. In this study, single chamber MFC and double chambers MFCs were used to production and enrichment a microbial consortium for electricity generation from organic waste samples. Potential electrogenic bacteria were also isolated from anode, analyzed and evaluated. Most of them were Gram negative and fermentative organisms. Their electrogenic role was promising generating upto 5.05 volts and $4.72 \mathrm{~mA}$ when combined five) double chambers in series connection. Isolation of these bacteria and employing these for generation of electricity may bring potential power sector endeavor in future.
\end{abstract}

Keywords: Microbial fuel cell (MFC); Sludge waste; Electricity.

\section{Introduction}

It has been long viewed that the energy is one of the most essential needs in human's fundamental demands. It is also considered as the main source in developing and supporting economic growth and in upgrading the standard of living. Energy sources can be classified into three groups: fossil fuel, renewable sources and nuclear sources. Fossil fuels cause emission of carbon dioxide that affects the nature negatively through global warming and atmospheric pollution ${ }^{1}$. Besides these, today we are facing a huge energy crisis due to rapid depleting of unsustainable natural sources. It is an immediate need to find an effective alternative source for energy generation. Renewable energy sources such as solar energy, energy produced from wind and water may be a piece of cogent solution for this energy crisis. Many countries in the world are giving remarkable efforts for generating energy from renewable sources. Fuel cell (FC) which generates energy using high value metal catalysts (in the traditional version) has been proposed latterly as alternative energy source is an upshot of these efforts ${ }^{2}$. Chemical energy of fuels such as hydrogen, natural gas, methanol, etc., existing in the chemical bonds is directly converted into electricity by fuel cells ${ }^{3}$. Biological fuel cells (BFCs) use biocatalysts (microbes or enzymes) instead of expensive metal catalysts used in conventional fuel cells to produce bioelectricity. The main types of BFCs are defined based on biocatalysts used in anode compartment. Microbial fuel cells (MFCs) employ living cells for oxidation of organic substrate, whereas enzymatic fuel cells use active enzymes for the same purposes $^{4,5}$. Though the first fuel cell was built in 1839, Potter described microbial conversion to create electrical current in $1911^{6}$. However, MFC gained much attention in 1999 once it was discovered that mediator was not a compulsory component within $\mathrm{MFCs}^{7}$. In addition, the discovery of electricity production from wastes and renewable biomass using bacteria paves the way to MFC research field ${ }^{8}$. Furthermore, MFC technology was highlighted more when Time Magazine declared Geobacter sulfurreducens KN400, a bacterial strain capable of high current production, as one of the top 50 most important inventions for $2009^{9}$.

A great advantage of MFCs is that they typically have long lifetimes (up to five years) ${ }^{10,11}$. Additionally, they are able to oxidize simple carbohydrates to carbon dioxide via biochemical reactions as well as can be operated in mild conditions ${ }^{12,13}$. Therefore, MFC could play major role in green technology not only for the production of bioenergy but also fortreatingwastewater ${ }^{14}$. But a challenge is MFCs produce low energy which is currently orders of magnitude lower compared to that of chemical fuel cells ${ }^{15}$. Herein, the aim of this study was to produce electrical power from waste sludge by using microbial habitat in the waste samples. Furthermore, we would like to isolate and detect potential electrogenic bacterial (EB) isolates in Microbial Fuel Cell (MFC).

\section{Materials and Methods}

Sample collection: Samples (waste water) were collected from Fisheryghat/Sadarghat area of Chittagong City and Ashulia, Savar area of Dhaka City in Bangladesh by sterile bottles and bags. 
Then the samples were carried to Microbial Biotechnology Division Lab of National Institute of Biotechnology (NIB) for further studies.

Double Chamber MFC Design: The microbial fuel cell was consisted of two chambers, one contained anode and another one contained cathode. These compartments were separated by a U-shaped salt bridge, which was prepared by $5.0 \mathrm{M} \mathrm{NaCl}$ and $10 \%$ agar. zinc plate was used as anode and copper plate was used as cathode.

The anodic chamber contained basal medium of following compositions along with the waste sludge (per liter): $3 \mathrm{~g}$ glucose, $0.25 \mathrm{~g} \mathrm{NaHPO}_{4}, 0.25 \mathrm{~g} \mathrm{Na}_{2} \mathrm{HPO}_{4}, 0.3 \mathrm{~g} \mathrm{MgCl}_{2}, 0.005 \mathrm{~g} \mathrm{CaCl}_{2}$, $0.015 \mathrm{~g} \mathrm{ZnCl}_{2}, 0.0105 \mathrm{~g} \mathrm{CuCl}_{2}, 0.0105 \mathrm{~g} \mathrm{MnCl}_{2}, 0.5 \mathrm{~g} \mathrm{NH}_{4} \mathrm{Cl}$. The cathodic chamber contained distilled water and $0.1 \mathrm{M}$ phosphate buffer in 4:6 ratio ( $\mathrm{pH} 7.0)$. The mechanical aeration was also provided in the anode chamber by artificial oxygen pump. Anode chamber was enclosed for maintaining anaerobic condition. By using multimeter, electricity generation was measured from $1^{\text {st }}$ day to $20^{\text {th }}$ day, comparing with control value. Anode control chamber cantained $0.1 \mathrm{M}$ Phosphate buffer or normal tape water and cathode control chamber contained $0.5 \mathrm{M}$ Phospate buffer or normal tape water.

Multiple Chambers Containing MFC Design: In this type, four double chamber MFC were connected where each anode was connected to the cathode of just next chamber in series. cathode was the first chamber and anode was the last chamber, which were connected to each other through electric bulb (Figure 1)

SEM Analysis of Anode: For scanning electron micrograph (SEM) analysis, the anode plates were collected from different anode chamber carefully because anode plate surface which dipped in the sample was full of microbial biofilm. The anode plates were cut into small pieces $(1 \mathrm{~cm} \times 1 \mathrm{~cm})$ aseptically with sterile saw in LAF (Laminar Air Flow). The small pieces were immersed into the sterile basal medium which was composed of as follows (g/l): Glucose 3.0, $\mathrm{NH}_{4} \mathrm{Cl}$ 0.5, $\mathrm{NaHPO}_{4}$ 0.25, $\mathrm{Na}_{2} \mathrm{HPO}_{4} 0.25, \mathrm{MgCl}_{2} 0.3, \mathrm{CaCl}_{2} 0.005, \mathrm{ZnCl}_{2} 0.015, \mathrm{CuCl}_{2}$ $0.0105, \mathrm{MnCl}_{2} 0.0105$ and $\mathrm{pH}$ was 7.5 . Basal medium was used to enhance the growth of microbial biofilm. Pieces of anode were incubated for 5 days to remove excess water. Then the anode pieces of zinc plate were taken to BUET for capturing Scanning Electron Microscopic (SEM) images.

Isolation of Viable Bacteria from Anode: The anode plate immerse in MFC was carried out with full bacteria and placed on nutrient agar media for their growth. After overnight incubation at $37^{\circ} \mathrm{C}$, the whole selective processes of isolation was carried out and total electrogenic bacteria load per $\mathrm{ml}$ was calculated following the formula given below-

Viable bacteria count $/ \mathrm{ml}=$ (the total number of bacteria colonies $\times$ Dilution factor $) \div$ volume of sample added to the agar plate.

Potential Electrogenic Bacteria Determination: Each isolated bacterial pure culture was inoculated in $100 \mathrm{ml}$ sterile nutrient broth and incubated for over night at $37^{\circ} \mathrm{C}$ and $150 \mathrm{rpm}$. After incubation OD (Optical Density) values of cell density were measured.

Microscopic Examination and Biochemical Characteristics: Gram staining has been used to determine the microscopic appearance of the isolated bacteria which were potential for electricity generation. For the identification of the isolated bacteria, 15 different biochemical tests were performed. These were Voges Proskauer (VP), methyl red test (MR), indole production test, catalase test, oxidase test, tripple sugar iron test (TSI), nitrate reduction test, glucose fermentation test, motility test, gelatin hydrolysis test, $\mathrm{H}_{2} \mathrm{~S}$ gas production test, starch hydrolysis test, Simon citrate test, urease test and growth on MacConkey agar. Biochemical tests have been done by comparing with negative control where applicable.

\section{Results}

Electricity Generation by Double Chamber MFC: In double chamber MFC, anode and cathode were connected with the salt bridge and electricity generation was measured with a multi-meter, initially it showed insignificance volt. With the span of time the volt value of multi-meter was increased. It was started to increase from $2^{\text {nd }}$ day to $5^{\text {th }}$ day and then it was started to decrease due to depletion of nutrients. After $5^{\text {th }}$ day the value of the multi-meter value started to increase when $3 \mathrm{gm}$ glucose solution was added to the anode chamber. After 5 days of glucose addition multimeter value was started to go down again (Figure 1).

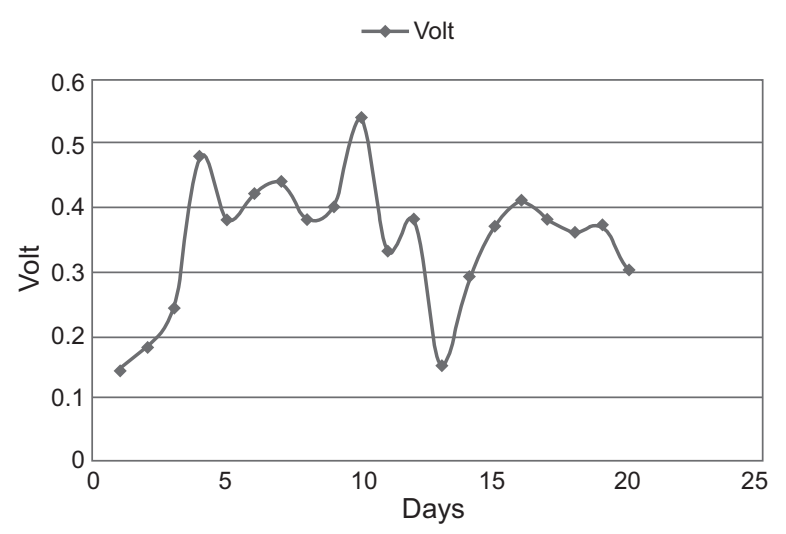

Figure 1. Graphical presentation of electricity generation of double chamber microbial fuel cell (MFC).

Electricity Generation by Multi-chambers Connected in Series: Individual generation of electricity is very low in double chamber MFC for illumination of light. It can be increased by designing multiple chambers MFC. Multiple chambers MFC provided optimal result than double chamber MFC. Five double chambers were connected in series. Therefore, the electricity generation was higher than double chamber MFC as shown in Figure 2.

Scanning Electron Microscope analysis: MFC $\notin s$ anode was an excellent source of electrogenic bacterial biofilm. The bacteria attached with anode were clearly observed under scanning electron microscope (Figure 3). The SEM was operated at $15 \mathrm{KV}$ and images were digitally captured ${ }^{16}$. 


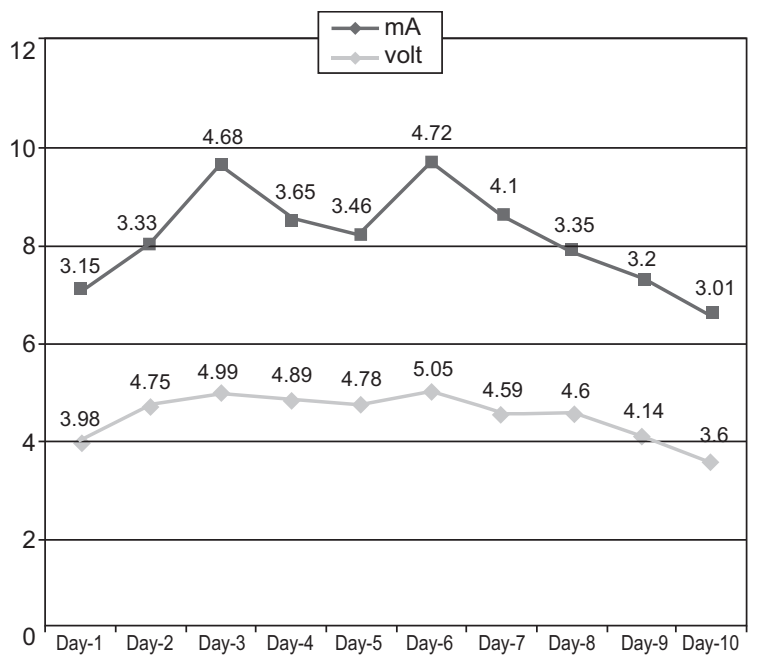

Figure 2. Graphical presentation of Electricity generation of multiple chambers microbial fuel cell (MFC); Volt and ampere are changed simultaneously.

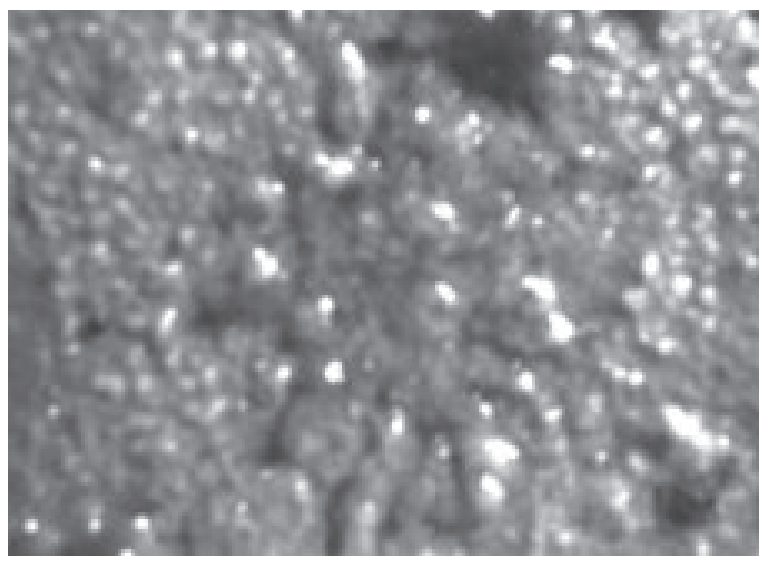

Figure 3. Scanning electron microscope (SEM) images of Zinc plate (anode); presence of electrogenic bacteria was confirmed.

Biochemical Identification: Total 19 isolates were tested for biochemical reactions such as indole test, MR test, VP test, nitrate test, urease test, catalase test, oxidase test, gelatin hydrolysis, Simon citrate, starch hydrolysis, glucose fermentation, etc., as described in Table 1.

Table 1. Potential electrogenic bacterial biochemical test results $(n=19)$.

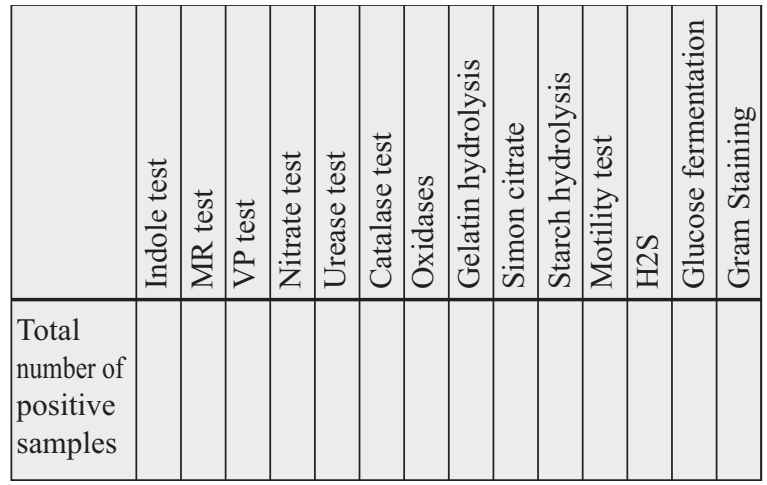

' $\mathrm{n}$ ' indicates total number of samples

\section{Discussions}

MFC is a state-of-the-art technology for production of electricity from metabolism of microorganisms. Till now, many microbes and a variety of waste substrates (including waste and xenobiotics) have been used to produce electricity. The focus of this study was to isolate and enrich a microbial consortium for electricity generation from organic waste samples. It is remarkable that the organisms that have been studied in detail, among them Bacillus licheniformis and G. sulfurreducens produce electricity above $1 \mathrm{~V}$ per day ${ }^{16}$. In this study, Bacillus $s p$. and Bacillus licheniformis were found that can produce electricity $0.93 \mathrm{~V}$ and $0.95 \mathrm{~V}$ respectively, which is in consistent with other study ${ }^{16}$. So, it's great hope to generate electricity by using MFC from Organic waste. The success of specific MFC applications will depend on the concentration and biodegradability of the organic matter in the influent, waste temperature and the absence of toxic chemicals. However, a major drawback of this technology is that the power output is very low and scaling up leads to a decrease in power output $^{17}$. Hence, a lot more work is required so that this technology becomes efficient, applicable and widely acceptable. Improvement of MFC design will make other tasks vitally important for their further development. These tasks include better understanding of the nature of electrogenic communities, of the role of individual bacteria in these communities, of the mechanisms of electron transfer to the electrodes and between microbial cells and of the metabolic pathways and physiology of electrogenic bacteria.

In Bangladesh, waste management and treatment are not progressing like the developed countries. However, this study may denote that the used organics can be a potential source of electricity generation and may be a solution for waste treatment as well. Every year Bangladesh need to import a considerable amount of petroleum energy from other countries, which implies a huge cost. In this situation, renewable energy source is the only solution of energy management for future days. The development of Microbial fuel cells may reduce the presence energy cost and provide new opportunities for the sustainable production of energy from biodegradable compounds in Bangladesh. The use of potential bacteria in case of waste organics treatment is environment friendly and regarded as renewable energy source, though MFC produces a minimal electricity. In near future, the research with MFC may bring a beneficial result for human being with significant renewable sources of energy.

\section{Acknowledgement}

The study was funded by National Institute of Biotechnology, Ministry of Science and Technology, Bangladesh. We are grateful to the laboratory staffs for their cooperation in this study.

\section{Conflict of interest}

Authors have declared that they have no competing interest. 


\section{References}

1. Rahimnejad M, Ghoreyshi AA, Najafpour GD, Younesi H and Shakeri M. 2012. A novel microbial fuel cell stack for continuous production of clean energy. Int. J. Hydrogen Energy 37: 5992-6000.

2. Rahimnejad M, Adhami A, Darvari S, Zirepour A and Oh SE. 2015. Microbial fuel cell as new technol ogy for bioelectricity generation: A review. Alexandria Eng. J. 54: 745-756.

3. Steele BCH HA. 2001. No TMaterials for fuel-cell technologies. Natureitle. Nature 414: 345-52.

4. Minteer SD, Liaw BY and Cooney MJ. 2007. Enzyme-based biofuel cells. Curr. Opin. Biotechnolgy 18: 228-234.

5. Najafpour GD, Daud WRW and Ghoreyshi AA. 2009. Low Voltage Power Generation in aBiofuel Cell Using Anaerobic Cultures. 6: 1585-1588.

6. Potter MC. 1911. Electrical Effects Accompanying the Decomposition of Organic Compounds the Decomtposition Electrical Effects accompanying of Organic the fermentative activity of yeast and other organisms . Cultures of. Proc. R. Soc. London 84: 260-276.

7. Joo H et al. 2002. A mediator-less microbial fuel cell using a metal reducing bacterium, Shewanella putrefaciens. 30: 145-152.

8. Bond DR, Bond DR, Holmes DE and Tender LM. 2014. ElectrodeReducing Microorganisms That Harvest Energy from Marine Sediments. 483.

9. Time. 2009. The 50 Best Inventions of 2009.
10. Moon H, Chang IS and Kim BH. 2006. Continuous electricity production from artificial wastewater using a mediator-less microbial fuel cell. 97: 621-627.

11. Kim BH, Chang IS, Gil GC, Park HS, KH. 2003. Novel BOD (biological oxygen demand) sensor using mediator-less microbial fuel cell. Biotechnol. Lett 25: 541-5.

12. Loosdrecht MCM. Van \& Head, ÆIM. 2010. Modelling microbial fuel cells with suspended cells and added electron transfer mediator. 151162. doi:10.1007/s10800-009-9991-2

13. Bond DR, Lovley DR, Bond DR and Lovley DR. 2005. Evidence for Involvement of an Electron Shuttle in Electricity Generation by Geothrix fermentans Evidence for Involvement of an Electron Shuttle in Electricity Generation by Geothrix fermentans. 71 .

14. Deval A and Dikshit AK. 2013. Construction, Working and Standardization of Microbial Fuel Cell. APCBEE Procedia 5: 59-63.

15. Santoro C, Arbizzani C, Erable B and Ieropoulos I. 2017. Microbial fuel cells: From fundamentals to applications. A review. J. Power Sources 356: $225-244$

16. Bond DR and Lovley DR. 2003. Electricity Production by Geobacter sulfurreducens Attached to Electrodes Electricity Production by Geobacter sulfurreducens Attached to Electrodes. Appl. Environ. Microbiol. 69: $1548-1555$.

17. Santoro C, Flores-Cadengo C, Soavi F, et al. 2018. Ceramic Microbial Fuel Cells Stack: power generation in standard and supercapacitive mode. Scientific Reports. 8: 3281 